Bilgi, A. D., Aslan, D. ve Açıkgöz, G. (2020). Okul öncesi dönemdeki çocukların yazı farkındalığı becerilerini değerlendirme aracının geçerlik ve güvenirlik çalışması. Ana Dili Eğitimi Dergisi, 8(1), 24-43.

\begin{tabular}{c} 
Ana Dili Eğitimi Dergisi \\
$\begin{array}{c}\text { Journal of Mother Tongue Education } \\
\text { www.anadiliegitimi.com }\end{array}$ \\
$\begin{array}{c}\text { Geliş/Received: } 29.08 .2019 \text { Kabul/Accepted:09.12.2019 } \\
\text { Araştrma Makalesi / Research Paper }\end{array}$ \\
\hline
\end{tabular}

\title{
Okul Öncesi Dönemdeki Çocukların Yazı Farkındalığı Becerilerini Değerlendirme Aracı'nın Geçerlik ve Güvenirlik Çalışması
}

\author{
Arzu DOĞANAY BILGi* \\ Davut ASLAN** \\ Gökhan AÇIKGÖZ $Z^{* * *}$
}

\begin{abstract}
Öz
Bu araştırmanın amacı, okul öncesi dönemdeki çocukların yazı farkındalığı becerilerini değerlendirebilecek geçerli ve güvenilir bir ölçme aracının geliştirilmesidir. Araştırmada genel tarama modellerinden betimsel tarama modeli kullanılmıştır. Araştırmanın çalışma grubunu 4872 ay arası normal gelişim gösteren 109 kız, 107 erkek olmak üzere toplam 216 çocuk oluşturmuştur. Çalışma grubundaki çocuklar, Ankara ilinin sosyo-ekonomik düzeyi birbirinden farklı dört ilçesindeki bağımsız anaokullarında öğrenim görmektedir. Yazı Farkındalığı Becerilerini Değerlendirme Aracı'nın geçerlik çalışması için kapsam ve yapı geçerliği yapılmışır. Kapsam geçerliği için uzman görüşüne başvurulmuş, yapı geçerliği için ise madde analizi yapılmışır. Ayrıca üç faktörlü olarak kurulan modelin veriye uyum sağlayıp sağlamadığını belirlemek için Doğrulayıcı Faktör Analizi yapılmıştır. Değerlendirme aracının KR-20 güvenirlik katsayısı 0.76 olarak saptanmıştır. Araştırma sonucunda Yazı Farkındalığı Becerilerini Değerlendirme Aracı'nın okul öncesi dönemdeki 48-72 aylık çocukların yazı farkındalığı becerilerini değerlendirmede geçerli ve güvenilir bir araç olduğu belirlenmiştir.
\end{abstract}

Anahtar Kelimeler: Değerlendirme, erken okuryazarlık becerileri, okul öncesi eğitim, yazı farkındalığı

\section{A Validity and Reliability Study of the Preschool Children's Print Awareness Skills Assessment Form}

\begin{abstract}
This study aims to develop a valid and reliable assessment instrument that can assess the print awareness skills of preschool children. The research design used was the descriptive survey model. The study group consisted of 216 children - 109 girls and 107 boys, who were between the ages of 48-72 months and displayed normal development. Children in the study group were selected from six kindergartens in four different socio-economic level districts in the city of Ankara. For the validation of the print Assessment Tool for Print Awareness Skills (ATPAS), content and construct validity analyses were done. Expert opinion was obtained for content validity and item analysis was conducted for construct validity. In addition, Confirmatory Factor Analysis was done to determine whether the three-factor model found fit the data. The KR-20 reliability coefficient of the assessment tool was 0.76 . As a result, ATPAS was found to be a valid and reliable tool for assessing the print awareness skills of 48-72 month-old children.
\end{abstract}

Keywords: Assessment, early literacy skills, preschool education, print awareness

\footnotetext{
* Dr. Gazi Üniversitesi, Gazi Eğitim Fakültesi, Özel Eğitim Bölümü, Ankara, arzudb@gazi.edu.tr, ORCID: 00000003-3330-8303

${ }^{* *}$ Leeds University, Faculty of Social Science, School of Education, Leeds, ml17da@leeds.ac.uk, ORCID: 00000002-6361-7740

*** Gazi Üniversitesi, Gazi Eğitim Fakültesi, Özel Eğitim Bölümü, Ankara, gokhanacikgoz@gazi.edu.tr, ORCID: 0000-0002-8548-4360
} 


\section{Giriş}

Okul öncesi dönem çocukların gelişim ve öğrenmeleri için önemli bir zaman dilimidir. Çocuklar bu dönemde okuma yazma için gerekli ön becerileri kazanır ve okuryazar olmanın ilk adımlarını atarlar. Okuma yazma gelişiminin öncül becerileri; dinlediğini anlama ve sözcük dağarcığı, yazı farkındalığı ile yazı kavramları, alfabe-harf bilgisi, harf-ses ilişkisinin ve alfabetik ilkelerin anlaşılması ve sesbilgisel farkındalıktır (McGee \& Morrow, 2005; McGee \& Richgels, 2014). Yapılan pek çok araştırma ile erken okuryazarlık becerileri olarak adlandırılan bu becerilerin çocukların ilkokul yıllarındaki okuma başarısının güçlü birer yordayıcısı olduğu belirlenmiştir (Carroll, Snowling, Hulme, \& Stevenson, 2003; Lerkkanen, Rasku-Puttonen, Aunola, \& Nurmi, 2004; Spira, Bracken, \& Fischel, 2005; Vellutino, Scanlon, \& Lyon, 2003). Ayrıca erken okuryazarlık becerilerine sahip olan çocukların, bu becerilere sahip olmayanlara kıyasla ilk okuma yazmayı öğrenmede daha hızlı ve kolay bir süreç geçirdikleri de gösterilmiştir (Justice, Bowles, \& Skibbe, 2006; Storch \& Whitehurst, 2002; Walpole, Chow, \& Justice, 2004).

Çocukların okuma-yazma öğrenme süreçlerini belirlemek son yıllarda araştırmacılar için önemli bir çalışma alanı olmuştur. Alanda yapılan araştırmaların önemli bulgularından biri yazı farkındalığının okuma gelişimi üzerindeki güçlü etkisini ortaya koymak olmuştur (Farver, Nakamoto, \& Lonigan, 2007; Justice \& Ezell, 2001, 2004; Kelman, 2006). Dolayısıyla okuma yazma gelişiminde yazı farkındalığı ve yazı kavramları önemli alanlardır. Yazı farkındalığı temel olarak yazının resimlerden ve sözel dilden ayrı bir mesaj taşıdığı, yazının bir iletişim aracı olduğu ve yazı ile konuşma arasında bir ilişki olduğunun farkına varılmasıdır (Ezell \& Justice, 2005). Yazının farkında olmak ve yazıyı keşfetmek, çocukların yazı ile ilgili kavramlar oluşturmasını sağlar. Yazı formları bilgisi, yazı düzeni ve kitap düzenini içeren yazı kavramları ise yazılı bilgiyi yorumlamak için bağlamsal bir çerçeve sunan becerilerdir (van Kleeck, 2003). Lovelace ve Stewart'e (2007) göre yazı formları bilgisi yazının isimlendirilebildiğinin ve farklılaşabildiğinin anlaşılmasıdır. Yazı düzeni bilgisi de yazının bir organizasyonel şemaya sahip olduğu bilgisidir. Yani yazının nereden okunmaya başlandığının, okumanın nerede bitirildiğinin, yazının soldan sağa ve yukarıdan aşağı doğru okunduğunun ve bir satırdan diğerine geçilen, bir sayfadan diğerine geçilen bir düzeninin olduğunun anlaşılmasıdır. Kitap düzeni bilgisi ise kitapların nasıl oluşturulduğunun ve nasıl bir işlevi olduğunun farkına varılmasıdır (Lovelace \& Stewart, 2007). Örneğin; kitaptaki öyküyü bir yazarın yazdığının, resimlerinin ressamlarca çizildiğinin, kitapların başlıkları olduğunun, kitapların ön ve arka yüzü olduğunun çocuklar tarafından anlaşılmasıdır. Ayrıca harfler (harfleri sözcüklerden ve diğer şekillerden ayırma, harf kavramı, büyükküçük harfleri ayrıt etme vb.), sözcükler (harf ve sözcük arasındaki fark, uzun ve kısa sözcükleri ayırt etme, belirli sözcükleri tanıma vb.) ve noktalama işaretleri de (noktalama işaretlerini tanıma ve kullanım amacını bilme vb.) yazı farkındalığının bileşenleri olarak tanımlanmaktadır (Israel, 2008; Justice \& Sofka, 2010; McGee \& Richgels, 2014). Yazı farkındalığı ve yazı kavramlarının değerlendirilmesi ve öğretilmesi, çocukların sonraki okuryazarlık yeterliliğine bir köprü oluşturmaktadır (Reutzel, 2015). Pek çok araştırmada yazı farkındalığı becerilerinin çocukların gelecekteki okuma başarııını anlamlı bir şekilde yordadığı gösterilmiştir (Örn; Farver ve diğerleri, 2007; Hammill, 2004; Spira ve diğerleri, 2005; Vellutino ve diğerleri, 2003).

Çocuklar yazı farkındalığı becerilerini yetişkinlerle okuma-yazma temelli etkileşimlere girerek geliştirir; yazı ile ilgili ilk bilgilerini çevrelerindeki yazıları inceleyerek ve etraflarındaki kişilerin yazılı materyalleri nasıl kullandıklarını gözlemleyerek edinirler (Ezell \& Justice, 2005; Justice \& Sofka, 2010; Pullen \& Justice, 2003). Ancak çeşitli nedenlerden dolayı erken çocukluk döneminde çocukların yazı hakkında bilmedikleri pek çok şey olabilmekte ve yazı farkındalığı becerilerinin gelişiminde çeşitli problemler olabilmektedir (McGee \& Morrow, 2005; Pullen \& Justice, 2003). Çocukların bazıları ad ve soyadlarını ve bazı birkaç farklı kelimeyi yazmayı, alfabedeki çeşitli harfleri isimlendirmeyi öğrenmiş, yazının işlevini fark etmiş olarak anaokuluna başlarken, bazıları da adlarının nasıl yazııdığını bilmeyerek, alfabedeki hiçbir harfi tanımayarak ya da hiç yazı bilgisine sahip olmayarak anaokuluna başlamaktadır (McGee \& Morrow, 2005). Yazı farkındalığı becerilerinde yaşanan gecikmeler anaokulu yılları boyunca da devam edebilmektedir. Okul öncesi dönemde erken okuryazarlık becerilerinin kazanılmamış olması daha ileri seviyedeki okuma yazma gelişiminde ortaya çıkabilecek zorluklara 
yönelik önemli bir uyarı olabilir (Justice \& Ezell, 2001). Yazı farkındalığının sonraki okuma yazma becerilerine yönelik önemi göz önünde bulundurulduğunda bu uyarının dikkate alınarak okul öncesi dönemde yazma gelişiminde zorluk yaşayan çocukların belirlenmesi gerekli müdahalenin yapılabilmesi için oldukça önemlidir (Justice ve diğerleri, 2006). Özellikle düşük sosyo-ekonomik bir çevrede büyüyen, erken okuryazarlık becerileri ile ilgili bilgi ve deneyimleri sınırlı olan, dil ve konuşma bozuklukları ve gelişimsel yetersizlikleri olan çocuklar okuma yazma gelişimleri bakımından risk altındadırlar (Arnold \& Doctoroff, 2003; Ezell \& Justice, 2005; Justice \& Pullen, 2003; McGee \& Richgels, 2014). Örneğin dil ve konuşma bozuklukları en bilinen risk faktörlerinden biridir ve çocukların erken okuryazarlık becerilerini geliştirememelerine, bunun sonucu olarak da ilkokul yıllarında okuma güçlüğü sergilemelerine neden olabilmektedir (Catts, Fey, Tomblin, \& Zhang, 2002; McCardle, Scarborough, \& Catts, 2001).

Okuma başarısı için diğer bir risk faktörü ise çocuğun yetersiz sosyo-ekonomik bir ortamda büyümesidir. Düşük okuma başarısı ile sosyo-ekonomik yönden yetersiz bir ortamda büyüme arasında yüksek bir korelasyon bulunmaktadır (Lonigan ve diğerleri, 1999; McGee \& Richgels, 2014). Yetersiz sosyo-ekonomik bir ortamda büyüyen çocuklar, genellikle aynı çevreden gelen diğer çocuklarla aynı okullara devam etmektedirler. Bu nedenle sosyo-ekonomik seviyenin kümülatif bir etkisi vardır ve ağırlıklı olarak düşük sosyo-ekonomik düzeyli çocukların devam ettiği okullara giden düşük sosyo-ekonomik düzeyli ailelerin çocukları okuma güçlüğü açısından en yüksek riske sahip olanlardır (Cabell, Justice, Konold \& McGinty, 2011; Ghosh, 2013; McGee \& Richgels, 2014). Sosyoekonomik yönden yetersiz bir ortam aynı zamanda okuma yazma gelişimi için çok önemli olan erken okuryazarlık becerileri ile ilgili çocukların yeterli bilgi ve yaşantı kazanamamalarına neden olmaktadır. Özellikle bu ortamlarda anne-babanın yetersiz okuryazar olması, anne-babanın okuryazarlığa yönelik olumlu olmayan tutumları ve okuma-yazma konusunda çocuklarına daha az model olmaları, evde ya da okulda çocuklara sağlanan okuryazarlık fırsatlarının nicelik ve niteliğinin yetersiz olması, erken okuryazarlık materyallerine erişimde sınırlılık gibi faktörler çocukların okuma-yazma aktivitelerine daha az katılımına neden olmaktadır (Ezell \& Justice, 2005; Foster, Lambert, Abbott-Shim, McCarty, \& Franze, 2005; McGee \& Richgels, 2014; Snow, Burns \& Griffin, 1998). Bu durum çocukların yazı ile tanışıklıklarının az olmasına, yazının işlevini öğrenmede gecikmeler yaşanmasına ve dolayısıyla yazı farkındalığı becerilerinin ve yazı bilgisi kavramlarının geç kazanılmasına neden olmaktadır. Kısacası hem çevresel hem de gelişimsel risklerde, çocuklar yazı kavramları gelişiminde benzer dezavantajlara sahiptirler (Justice ve diğerleri, 2006).

Okuma başarısızlığı genel olarak okulun ilk yıllarında ve özellikle de ilk okuma yazma becerilerinde karşılaşılan güçlüklerle kendini göstermektedir ve çoğu zaman müdahaleler güçlüklerin farkına varılmasından sonra gerçekleşmektedir. Ancak okul öncesi dönemde okuma süreci ve okuma yazma başarısını yordayan becerileri belirleme üzerine yapılan araştırmalarla okuma güçlüklerine yatkınlığı olan çocukları formal okuma yazma öğretiminden önce belirlemenin mümkün olduğu (Pesova, Sivevska, \& Runceva, 2014; Carroll, Solity, \& Shapiro, 2016), bu çocuklara özellikle erken okuryazarlık becerilerinin kazandırılarak okuma yazma gelişim sürecini hızlandırmanın ve gecikmeleri hafifleten delile dayalı erken müdahalelerin olanaklı olduğu gösterilmiştir (Justice \& Ezell, 2000; 2002; Justice \& Pullen, 2003). Bu erken müdahale programlarının temel amacı, okuma başarısı risk altındaki çocukların okuma yazma gelişimlerinde gereksinim duyduğu alanlarla ilgili mevcut becerilerini artırmak ve ileri dönemlerde risk altında olmayan akranları ile eşit düzeyde eğitim olanaklarından yararlanmalarını sağlamaktadır. Güçlükler ortaya çıktıktan sonra değil, erken müdahale programlarının önleyicilik ilkesinden yola çıkılarak, erken dönemde uygulanan erken müdahale programları yardımıyla çocukların sonraki okuma yazma becerilerinin çevresel ve gelişimsel yetersizliklerden daha az etkilendiği belirtilmiştir (Nancollis, Lawrie, \& Dodd, 2005). Sonuç olarak erken çocukluk döneminde çocuklardaki erken okuryazarlık problemlerinin değerlendirilerek belirlenmesi ve bu becerilerin geliştirilmesine yönelik erken müdahale programlarının uygulanması okuma yazma başarısızlıklarının önlenmesi veya azaltılması için önemli bir gerekliliktir. Bu durumda eğitimcilerin okul öncesi dönemde çocukların erken okuryazarlık becerilerini ölçebilecekleri ve problemlerini belirleyebilecekleri değerlendirme araçlarının olması gerekmektedir (Sodoro, Allinder, \& Rankin-Erickson, 2002). 
Ülkemizde de güvenilir ve geçerli bir biçimde erken okuryazarlık gelişiminde gecikme gösteren çocukları belirleyen ve erken okuryazarlık müdahalelerinin erken okuryazarlık becerileri üzerindeki etkililiğini betimleyen değerlendirme araçlarına gereksinim vardır. Aslında son yıllarda ülkemizde araştırmacıların okul öncesi dönem çocuklarının okuma yazma gelişimlerine ilişkin artan bir ilgi gösterdiği gözlenmektedir (Ergül ve diğerleri, 2016; Sarı \& Aktan-Acar, 2013; Işıkoğlu-Erdoğan, Muslugüme, Huz, Yılmaz, \& Öztürk, 2015) ve bunun bir sonucu olarak erken okuryazarlık becerilerinin değerlendirilmesi ve geliştirilmesine yönelik yapılan çalışmalar belli bir ivme kazanmıştır. Araştırma sayısının artmasına rağmen okul öncesi dönem çocukların yazı farkındalığı da dâhil olmak üzere tüm erken okuryazarlık becerilerini ölçmek amacı ile geliştirilmiş, geçerlik ve güvenirlik çalışmaları yapılmış sadece bir tane değerlendirme aracı bulunmaktadır (Karaman, 2013). Ayrıca okul öncesi dönem çocuklarının yazı farkındalığı becerilerini değerlendirebilmek için kullanılabilecek değerlendirme araçlarının sayısı da oldukça azdır (Bayraktar, 2013; Işıtan \& Akoğlu, 2016; Şimşek-Çetin \& Alisinanoğlu, 2013). Bu bağlamda okul öncesi dönem çocukların yazı farkındalığı becerilerinin değerlendirilmesinde kullanılan değerlendirme araçlarında çeşitliliğin sağlanması ve alternatif değerlendirme araçlarının geliştirilmesi bir gereksinim olarak görülebilir. Bu gereksinimden hareketle bu araştırmada, okul öncesi dönemdeki çocukların yazı farkındalığı becerilerini değerlendirmek amacıyla bir değerlendirme aracı geliştirmek ve geçerlik-güvenirlik çalışmalarını yapmak amaçlanmıştır.

\section{Yöntem}

Araştırmada betimsel tarama yöntemi kullanılarak, Yazı Farkındalığı Becerilerini Değerlendirme Aracı'ndan (YFDA) elde edilen sonuçların geçerlik ve güvenirliği ortaya konulmaya çalışımıştır.

\section{Çalışma Grubu}

Araştırmanın çalışma grubu, 2016-2017 eğitim öğretim yılında Ankara ilinin sosyo-ekonomik düzey açısından farklı seviyelerde bulunan dört ilçesinden Milli Eğitim Bakanlığı'na ait altı farklı bağımsız anaokulunda okul öncesi eğitimine devam eden 109 kız, 107 erkek olmak üzere toplam 216 öğrenciden oluşmaktadır.

Uygulama için gerekli yasal izinler alınmış, okul yönetimi, öğretmenler ve aileler çalışma hakkında bilgilendirilmiş ve izinleri alınmıştır. Ayrıca çocuklara da değerlendirme sürecinde kendilerine bir öykü kitabı okunacağı ve yazılarla ilgili bazı sorular sorulacağı belirtilerek çalışmaya katılıp katılmak istemedikleri sorulmuş, istediğini beyan eden çocuklarla uygulama gerçekleştirilmiştir. Çalışma grubunda yer alan çocuklar, belirlenen altı anaokulunda öğrenim gören çocuklar arasından gönüllülük esasına göre seçilmiş, ancak öğretmenler tarafından okuma yazmayı öğrenmiş olduğu ifade edilen çocuklar araştırmaya dâhil edilmemiştir. Tablo 1'de çocukların anaokuluna devam ettikleri ilçeler, okul sayısı, çocuk sayısı ve cinsiyetleri verilmiştir.

Tablo 1.

Çalışma grubundaki çocukların anaokuluna devam ettikleri ilçeler, okul sayısı, çocuk sayısı ve cinsiyetleri

\begin{tabular}{|c|c|c|c|c|c|}
\hline \multirow{2}{*}{$\begin{array}{l}\text { Sosyo-ekonomik } \\
\text { düzey (SED) }\end{array}$} & \multirow{2}{*}{ İlçeler } & \multirow{2}{*}{$\begin{array}{l}\text { Okul } \\
\text { Sayısı }\end{array}$} & \multirow{2}{*}{$\begin{array}{l}\text { Çocuk } \\
\text { Sayısı }\end{array}$} & \multicolumn{2}{|c|}{ Cinsiyet } \\
\hline & & & & $\mathrm{K} / \mathrm{Z}$ & Erkek \\
\hline Düşük SED & Mamak & 2 & 72 & 29 & 43 \\
\hline Orta SED & Yenimahalle & 1 & 36 & 18 & 18 \\
\hline Orta SED & Keçiören & 1 & 36 & 21 & 15 \\
\hline Yüksek SED & Çankaya & 2 & 72 & 41 & 31 \\
\hline Toplam & 4 & 6 & 216 & 109 & 107 \\
\hline
\end{tabular}




\section{Yazı Farkındalı̆ı Becerilerini Değerlendirme Aracının Geliştirilmesi}

Araştırma bağlamında YFDA'nın geliştirilme sürecinde öncelikle erken okuryazarlık becerileri, özellikle de yazı bilgisi ve yazı farkındalığının gelişimsel özellikleri ile ilgili alanyazın taranmış ve ilgili beceriler belirlenmiştir. Ayrıca uluslararası ve ulusal alanyazında yazı farkındalığı becerilerinin değerlendirilmesi amacıyla geliştirilen değerlendirme araçları incelenmiştir (Bayraktar, 2013, Justice \& Ezell, 2001; Invernizzi, Sullivan, Meier \& Swank, 2004; Işıtan \& Akoğlu, 2016; Şimşek-Çetin \& Alisinanoğlu, 2013). Sonuç olarak değerlendirme aracında olması gereken becerilere karar verilmiş ve değerlendirme aracını oluşturan maddeler belirlenmiştir. YFDA iki bölümden oluşmaktadır. ílk bölüm çalışma grubunda yer alan çocukların demografik bilgilerinin yer aldığı giriş bölümüdür. İkinci bölüm ise yazı farkındalığı becerileri ile ilgili olarak yazı yönü, kitap kavramları, yazı kavramları olmak üzere toplam üç faktör ve 27 maddeden oluşmaktadır. Değerlendirme aracının yazı yönü alt boyutunda kitabın tutuş şekli-tutuş yönü, yazının başlangıç ve bitiş yeri, yazının soldan sağa okunuş yönü, yazının yukarıdan aşağıya okunuş yönü, yazının okunuşundaki sayfa yönüne ilişkin sekiz madde; kitap kavramları alt boyutunda kitabın kapağı, kitabın ön ve arka yüzü, başlığı, yazarı, resimleyeni, yayınevi bilgisine ilişkin sekiz madde; yazı kavramları alt boyutunda ise yazı ve resim arasındaki ilişki, sözcük kavramı, aynı olan sözcükler, sözcük arası boşluklar, harf kavramı ile büyük/küçük harfler, nokta ve soru işaretine ilişkin 11 madde bulunmaktadır. Bölümlerde yer alan maddelerin yanı sıra YFDA'da bir uygulama yönergesi bulunmaktadır ve ayrıca değerlendirme maddelerinin yer aldığı bir sütun, bu maddelerin puanlandırıldığı bir değerlendirme sütunu ve bir "açıklama" sütunu yer almaktadır.

YFDA'da yer alan tüm maddelerin değerlendirilmesinde resimli bir öykü kitabından yararlanılmıştır. Öykü kitabının belirlenmesinde, alanyazında paylaşımlı kitap okuma programlarında yaygın olarak kabul gören resimli öykü kitaplarına ilişkin biçim ve içerik özellikleri (Ezell \& Justice, 2005) ve değerlendirme aracında yer alan maddeler temel alınarak araştırmacılar tarafından geliştirilen bir kontrol listesi kullanılmıştır. Kontrol listesi 13 maddeden oluşmuştur ve "Çok eksik, Eksik, Uygun, Çok Uygun" şeklinde olmak üzere dört dereceli bir değerlendirme formu olarak hazırlanmıştır. Kontrol listesindeki maddeler bağlamında araştırmacılar tarafından çeşitli resimli öykü kitapları; 48-72 aylık çocukların yaş ve ilgi alanlarına uygunluğu, kitaptaki kavramların, yazı miktarının ve cümle uzunluklarının bu yaş çocuklar için uygunluğu, öyküde yer alan kavramların resimlerle desteklenip desteklenmediği, öyküdeki olayların sıralamasının zamansal ve mantıksal olarak uygunluğu, resimler ile yazılı öykünün birbirine uyumu, kitaptaki yazı miktarının çocukların dikkat sürelerine uygunluğunu ve kitabın biçimsel özellikleri (sayfa sayısı, boyutu, resim ve çizimlerin anlaşılırlığı, kapağı vb.) bağlamında incelenmiştir. Araştırma için uygun olduğu düşünülen üç kitap belirlenmiş ve bu kitaplarla ilgili olarak uzman görüşüne başvurulmuştur. Yukarıda belirtilen kriterler çerçevesinde uzmanların da bu kitapları incelemeleri istenmiştir. Uzmanlardan gelen görüşler çerçevesinde en yüksek puanı alan Kök Yayıncılık'a ait 16 sayfalık "Oyuncu Bulut" (Birden, 2015) adlı resimli öykü kitabının araştırmada kullanılmasına karar verilmiştir.

\section{İşlem ve Veri Analizi \\ Kapsam geçerliği}

YFDA'nın kapsam geçerliğini belirlemek için toplam dokuz uzmandan görüş alınmıştır. YFDA üç farklı üniversitede dört farklı uzmanlık alanından sekiz öğretim elemanı ve yazı farkındalığı becerilerinin geliştirilmesine yönelik yüksek lisans tez çalışması olan bir özel eğitim öğretmeni tarafından değerlendirilmiştir. Özel eğitim alanında erken çocukluk, okuma-yazmaya hazırlık, ilk okuma yazma alanlarında çalışmaları bulunan üç uzmandan görüş alınmıştır. Okul öncesi eğitim alanından ise okul öncesi dönem çocuklarında okuma yazma gelişimi ve erken okuryazarlık ile ilgili çalışmaları bulunan üç uzmandan görüş alınmıştır. Türkçe Eğitimi ve Ölçme Değerlendirme alanlarından birer uzmandan ise değerlendirme aracını kendi uzmanlık alanlarına yönelik değerlendirmeleri istenmiştir. Uzmanlar her bir maddeyi amacına uygunluk, ilgili yaş grubuna uygunluk, maddelerin zorluk düzeyleri, yönergelerinin anlaşılırlığı ve puanlamanın uygunluğu açısından "Uygun, Düzeltmeli, Uygun Değil" şeklinde üçlü derecelendirme ile değerlendirmişlerdir. Ayrıca uzmanlardan uygun görmedikleri veya düzeltilmeli şeklinde görüş bildirdikleri maddelere ilişkin gerekçelerini belirten bir açıklama yazmaları da istenmiştir. Değerlendirme aracında bulunan 
27 madde de uzmanlar tarafından uygun bulunmuş, bunlar içinden düzeltilmesi yönünde görüş bildirilen beş maddenin uygulama yönergelerinde ve puanlamalarında gerekli düzenlemeler yapılmıştır. Uzmanların değerlendirmeleri sonucunda, değerlendirme aracının ölçülmesi amaçlanan kapsamı iyi düzeyde temsil ettiği kararına varılmıştır.

\section{Ön Uygulama}

Bu uygulama Ankara ili Çankaya Bölgesi'nde bulunan bağımsız bir anaokulunda öğrenim gören 48-72 aylık beş çocukla yürütülmüştür. Ön uygulama sonucunda uygulamanın daha hızlı ve akıcı yapılabilmesi için yazı yönüyle ilgili olan kitabın ters-düz tutuşunu belirlemeye yönelik maddenin değerlendirme aracındaki uygulama sırası değiştirilmiştir.

\section{Uygulama}

Araştırma bağlamında Ankara ili merkez ilçelerinde bulunan ve bağımsız anaokullarına devam etmekte olan $48-72$ ay arası toplam 216 çocuk ile değerlendirme çalışmaları yapılmıştır.

Değerlendirmeler sırasında Kök Yayıncılık'a ait 16 sayfalık “Oyuncu Bulut” (Birden, 2015) adlı resimli öykü kitabı kullanılmışır. Uygulama anaokulları yönetimlerinin göstermiş olduğu boş sınıflarda araştırmada yer alan üç araştırmacı tarafından gerçekleştirilmiştir ve çocuklarla birebir çalışılmıştır. Uygulama her hangi bir kayıt cihazı ile kayıt edilmemiş, uygulama sürecinde anında değerlendirme yapılmış ve kayıt tutulmuştur. Değerlendirme sırasında öykü kitabı okunurken çocuk ve araştırmacı küçük bir masanın etrafında yan yana oturmuştur. Resimli öykü kitabı çocuğun görebileceği bir şekilde tutularak ve yazıya işaret edilmeden okunmuştur. Okuma sırasında ilgili sayfada değerlendirme aracında yer alan sorular belirlenen sırayla ve sözlü olarak çocuğa sorulmuştur. Araştırmacı uygulamaya başlarken çocuğa öykü kitabını göstermiş, birkaç dakika kitabı incelemesine izin vermiş ve "Şimdi biz bu kitabı birlikte okuyacağız ve benim senin yardımına ihtiyacım var" yönergesini vermiştir. Uygulamada her soru bir kez sorulmuş, çocukların tepkilerine herhangi bir müdahalede bulunulmamış, yanlış ya da doğru tepkilerine herhangi bir geri bildirim verilmemiş, sadece soru karşısında çocuğun tepkisiz kalarak beklediği durumlarda soruyu anlamadığı varsayılmış ve soru bir kez tekrar edilmiştir. Çocuğun verdiği doğru tepkiler 1 puan, yanlış tepkiler ise 0 puan olarak değerlendirilmiştir. Her bir değerlendirme oturumu ortalama 13 dakika sürmüştür.

\section{Madde analizi}

YFDA'nın 216 çocuğa uygulanmasıyla elde edilen verilere ilk olarak madde analizi yapılarak madde istatistikleri hesaplanmıştır. Bu amaçla maddelere ait madde güçlük indeksi ve madde ayırt edicilik indeksleri hesaplanmıştır. Madde ayırt edicilik indeksi olarak nokta çift serili korelasyon katsayısı kullanılmıştır. Madde güçlük indeksi değeri 1'e yaklaştıkça maddeyi grubun çoğunluğunun doğru yaptığı ve kolay olduğu, 0 'a yaklaştıkça ise maddenin grubun çoğu tarafından yanlış cevaplandığı ve zor olduğu anlamına gelmektedir (Tan, 2010). Amaca göre farklılık gösterse de genel olarak bir test geliştirilirken madde güçlük indekslerinin ortalamasının 0.50 civarında olması ve bütün yetenek düzeylerine hitap edecek biçimde geniş bir ranjda dağılım göstermesi önemlidir (Tekindal, 2008). Madde ayırt edicilik katsayısı olarak kullanılan nokta çift serili korelasyon katsayısı, madde ile toplam test puanı arasında hesaplanan korelasyondur. Bu katsayının genel olarak 0.20 ve üzerinde olması beklenmektedir (Crocker \& Algina, 2006). Bu katsayının 0.20 ve üzerinde değer alması maddenin testin geneliyle uyumlu olduğu anlamına gelmektedir. Katsayının negatif değer alması durumunda madde testten çıkarılır.

YFDA toplamda üç faktörden oluşmaktadır. Değerlendirme aracına ait madde analizi yapıldıktan sonra bu maddelerin ilgili faktörlerin anlamlı bir yordayıcısı olup olmadığının tespiti ve üç faktörlü olarak kurulan modelin veriye uyum sağlayıp sağlamadığını belirlemek için Doğrulayıcı Faktör Analizi (DFA) yapılmıştır. Burada yapı geçerliği için DFA'nın tercih edilmesinin nedeni yazı farkındalığı becerileri ile ilgili alan yazından kaynaklanmaktadır. Kurulan üç faktörlü model alan yazına dayalı olarak oluşturulmuştur. Nitekim, Pohlmann (2004) faktör sayısına karar vermede, ilgili yapı ile ilgili önceki çalışmalar ve ilgili kuramın/teorinin çok önemli olduğunu belirtmiştir. Benzer şekilde 
Matsunaga (2010), DFA'nın var olan bir teoriyi test etmede, kurulan modelin veriye uyumlu olup olmadığını test etmede kullanılabileceğini belirtmişstir. Araştırma kapsamında kurulan modele ilişkin DFA Mplus7 programında yapılmıştır. Kestirim yöntemi olarak WLSMV (Robust Weighted Least Squares) kullanılmıştır. Bu kestirim yöntemi kategorik gösterge değişkenlerinin olduğu durumlarda daha uygun sonuçlar üretmektedir (Brown, 2015). Kurulan herhangi bir modelin veriye uyumunu değerlendirmek amacıyla pek çok uyum istatistiği kullanılmaktadır. Mplus programı DFA analizi çıktısı olarak RMSEA, CFI, TLI ve $\chi 2$ değerlerini vermektedir. Brown (2015), Mplus'ın programının SRMR değerini raporlamamasının nedeninin ikili gösterge değişkenlerin olduğu durumlarda SRMR'nin iyi performans göstermediğinden kaynaklandığını belirtmiştir. Yapılan bu araştırma kapsamında, $\chi 2$ (kikare), $\chi 2$ / sd (Serbestlik derecesi), RMSEA, CFI ve TLI değerleri yorumlanacaktır. Ki-kare değeri genellikle örneklem büyüklüğünden etkilendiği için $\chi 2$ / sd dikkate alınmaktadır. " $\chi 2$ / sd" oranının 5 'ten küçük çıkması, RMSEA değerinin .08'den düşük, buna karşlık CFI ve TLI değerinin ise .90 'dan yüksek çıkması modelin veriye uyumlu olduğunu göstermektedir (Çokluk, Şekercioğlu, \& Büyüköztürk, 2012).

\section{Bulgular}

Araştırmanın bu bölümünde 48-72 aylık çocukların yazı farkındalığını değerlendirmek amacıyla geliştirilen YFDA'ya ait madde analizleri ve bu ölçme aracının yapı geçerliğine ait elde edilen kanıtlar verilmiştir.

Araştırma kapsamında ilk formu 27 maddeden oluşturulan ve 216 çocuğa uygulanan YFDA'ya ait madde ayırt edicilik (Nokta çift serili korelasyon değerleri) ve madde güçlük indeksleri Tablo 2'de verilmiştir.

Tablo 2.

Yazı Farkındalığı Becerilerini Değerlendirme Aracı'na ait ilk formunun madde istatistikleri

\begin{tabular}{|c|c|c|c|}
\hline Maddeler & & $\begin{array}{l}\text { Madde } \\
\text { Gücclük } \\
\text { İndeksi }\end{array}$ & $\begin{array}{c}\text { Madde } \\
\text { Ayırıcılık } \\
\text { Indeksi }\end{array}$ \\
\hline \multicolumn{4}{|l|}{ Yazı Yönü } \\
\hline $\mathrm{m} 1$ & $\begin{array}{l}\text { Sen de kitaba bakmak ister misin? Al bakalım kitap } \\
\text { okunurken nasıl tutulur bana göster. }\end{array}$ & 0.99 & 0.08 \\
\hline $\mathrm{m} 13$ & $\begin{array}{l}\text { Kitapta ikinci sayfa işaret edilerek: Buraya bak, şimdi kitabı } \\
\text { okumaya başlayacağım. Yazıları nereden okumaya } \\
\text { başlayacağımı bana göster. }\end{array}$ & 0.62 & 0.76 \\
\hline $\mathrm{m} 14$ & $\begin{array}{l}\text { Kitabın ikinci sayfası işaret edilerek: Buraya bak, şimdi bu } \\
\text { sayfayı okuyacağım. Yazıları okumayı nerede bitireceğimi } \\
\text { bana göster. }\end{array}$ & 0.58 & 0.80 \\
\hline $\mathrm{m} 15$ & $\begin{array}{l}\text { Kitabın sol ve sağ sayfaları işaret edilerek: Bu iki sayfaya } \\
\text { bak, önce hangi sayfayı okuyacağım? Bana göster. }\end{array}$ & 0.86 & 0.51 \\
\hline $\mathrm{m} 16$ & $\begin{array}{l}\text { Sayfadaki ilk cümlenin ilk sözcüğü işaret edilerek: Şimdi ben } \\
\text { buradan okumaya başlıyorum, ne tarafa doğru okuyacağımı } \\
\text { parmağınla işaret ederek göster. }\end{array}$ & 0.91 & 0.54 \\
\hline m17 & $\begin{array}{l}\text { Sayfadaki ilk satır işaret edilerek: Sayfadaki bu ilk satırı } \\
\text { okumayı bitirdim, şimdi nereden okumaya devam } \\
\text { edeceğimi bana göster. }\end{array}$ & 0.85 & 0.60 \\
\hline $\mathrm{m} 18$ & $\begin{array}{l}\text { Kitabın sol sayfası işaret edilerek: Bu sayfayı okumayı } \\
\text { bitirdim, şimdi nereyi okuyacağımı bana göster. }\end{array}$ & 0.98 & 0.38 \\
\hline m19 & $\begin{array}{l}\text { Kitabın sağ sayfası işaret edilerek: Bu sayfayı okumayı } \\
\text { bitirdim, şimdi okumaya nereden devam edeceğim bana } \\
\text { göster. }\end{array}$ & 0.94 & 0.39 \\
\hline
\end{tabular}

Kitap Kavramları 
$\mathrm{m} 2$

Kitabın ön yüzü üste gelecek şekilde kitap masanın üstüne ve çocuğun önüne gelecek şekilde konarak: Kitabın ön yüzünü göster.

m3 Kitabın ön yüzü üste gelecek şekilde kitap masanın üstünde ve çocuğun önündeyken: Kitabın adı nerede yazıyor, göster.

m4 Kitabın adı işaret edilerek: Sence burada ne yazıyor olabilir? Söyle

m5 Kitabın ön yüzü üste gelecek şekilde kitap masanın üstünde ve çocuğun önündeyken: Kitabın arka yüzünü göster.

m6 Kitap yazan kişiye ne denir, söyle.

m7 Kitabın ön yüzü üste gelecek şekilde kitap masanın üstüne ve çocuğun önüne gelecek şekilde tekrar konarak: Kitabın yazarının adı nerede yazıyor, göster.

m8 Bir kitaptaki resimleri çizen kişiye ne denir, söyle

m9 Bu kitabın yayınevinin adı/logosu nerede? Göster.

\section{Yazı Kavramları}

m10 Bu sayfadaki resimleri göster.

m11 Bu sayfadaki yazıları göster.

m12 Kitaptaki ilk sayfa işaret edilerek: Bu sayfayı sana okumak istiyorum. Nereyi okuyacağımı bana göster.

m20 Bu sayfada bana bir sözcük göster.

m21 Bu sayfadaki yazıda kaç sözcük var, sayıp söyle.

m22 Bu sayfada birbirinin aynısı olan iki sözcük var. Bu sözcükleri bana göster.

m23 Bana bu cümlede sözcükler arasında bulunan boşluklardan bir tanesini göster.

m24 Bana bu sayfada bir harf göster.

m25 Bazı harfler küçük, bazı harfler büyük harflerdir. Bana bu sayfada büyük harf göster.

m26 Bu sayfadaki yazıda cümlelerin bittiğini anlamama yarayan birkaç tane nokta var. Bana bu noktalardan bir tanesini göster.

m27 Bu sayfadaki yazıda soru sorulduğunu anlamama yarayan bir soru işareti var. Bana bu soru işaretini göster.

$1.00 \quad 0.06$

$1.00 \quad 0.00$

$0.93 \quad 0.22$

$0.25 \quad 0.66$

$0.20 \quad 0.68$

$0.17 \quad 0.44$

$0.25 \quad 0.59$

Tablo 2'de görüldüğü üzere, 27 maddeye ait madde güçlük indeksleri 0.14 ile 1.00 arasında değişmektedir. Madde 1, 2, 5, 10,11, 12, 16, 18 ve 19'un madde güçlük düzeyi 0,90'nın üzerindedir. Bu maddeler grubun büyük çoğunluğu tarafından doğru olarak cevaplanmıştır. 6., 21. ve 22. maddelerinin ise madde güçlük düzeyleri 0.20 ve altındadır. Bu maddeler grubun çoğunluğu tarafından yanlış cevaplanmıştır. Testte yer alan maddelerin bir kısmının çok kolay, bir kısmının da çok zor olması çocukların yazı farkındalığı düzeylerinin farklı olmasından kaynaklanabilir. Ancak YFDA'daki maddelerin amacına hizmet etme düzeylerini yani grupta bilenle bilmeyeni ayırt edebilme düzeylerini belirlemek için testteki maddelere ait madde ayırt edicilik katsayısı olarak da kullanılan nokta çift serili korelasyon değerlerine bakılmıştır. Buna göre YFDA'da yer alan maddelere ait madde ayırt edicilik katsayıları dikkate alındığında, bu katsayıların 0.00 ile 0.80 arasında değiştiği görülmektedir. 1., 10. ve 11. maddelerin ayırt edicilikleri düşük hesaplanmıştır. Söz konusu maddelerin ayırıcılıklarının düşük hesaplanmasının nedeni grubun yaklaşık \%95 ve üstünün maddede yer alan görevi doğru bir şekilde cevaplandırmasından kaynaklanmaktadır. Bu da çocuklarda yazı farkındalığı düşük olsa da belirtilen maddeleri doğru cevapladıklarına işaret etmektedir. Bu nedenle maddelerin yazı farkındalığı için en alt beceriyi ölçtüğü söylenebilir. 
Bu doğrultuda 1., 10. ve 11. maddelerin ayırt edicilikleri düşük olduğu için bu maddelerin düzenlenmesi ya da değerlendirme aracından çıkarılması gerekmektedir. Öncelikle madde 1, 10 ve $11^{\prime}$ in madde ayırt edicilik değerleri 0'a çok yakın olduğu için bu maddelerin testten çıkarılıp çıkarılmaması konusunda iki uzmandan görüş alınmıştır. Buna göre, 1. madde de kitabın tutuş yönünün çocuklar için çok yaşantısal bir beceri olduğu, 10. maddede diğer maddelerden farklı olarak yazıya değil resimlere odaklanıldığı için bu maddelerin YFDA'daki diğer maddelerle benzer şekilde çalışmamış olabileceği belirtilmiştir. 11. maddede ise çocuğun yazıyı göstermesi herhangi bir sözcüğü göstermesinden çok daha geneldir ve rastgele bir yeri gösterdiğinde de yazıyı gösterme olasılığı yüksektir, o nedenle madde kolay çıkmıştır ve diğer maddelerde aynı faktör altında toplanmamıştır. Elde edilen bu görüşler doğrultusunda ve bu üç maddeye ait ayırt edicilik katsayılarının çok düşük çıkmasından dolayı 1., 10. ve 11. maddelerin testten çıkarılmasına karar verilmiştir.

Araştırmanın bulgulara göre Madde 6., 21. ve 22. maddelerinin madde güçlük düzeyleri 0.20 ve altındadır. Bu maddeler grubun çoğunluğu tarafından yanlış cevaplanmıştır. Testte yer alan maddelerin bir kısmının çok kolay, bir kısmının da çok zor olması çocukların yazı farkındalığı düzeylerinin farklı olmasından kaynaklanabilir. Ancak araştırmada YFDA'daki tüm maddelerin amacına hizmet etme düzeylerini yani grupta bilenle bilmeyeni ayırt edebilme düzeylerini belirlemek için testteki maddelere ait madde ayırt edicilik katsayısı olarak da kullanılan nokta çift serili korelasyon değerlerine de bakılmıştır. Bu maddelerin madde ayırt indeksleri Madde 6 için 0.45, Madde 21 için 0.68 , Madde 22 için ise 0.44 olarak elde edilmiştir. Madde ayırt edicilik katsayısı olarak kullanılan nokta çift serili korelasyon katsayısı, madde ile toplam test puanı arasında hesaplanan korelasyondur. Bu katsayının genel olarak 0.20 ve üzerinde olması beklenmektedir (Crocker \& Algina, 2006). Bu katsayının 0.20 ve üzerinde değer alması maddenin testin geneliyle uyumlu olduğu anlamına gelmektedir. Bu bağlamda bulgular değerlendirildiğinde ilgili maddelerin madde ayırt edicilik puanları 0.20'nin üzerinde bir değer alması nedeniyle testin geneli ile uyumlu olduğu görülmüştür. Ayrıca, madde seçiminde temel kriter olarak nadiren madde güçlüğü referans olarak alınmaktadır. Özellikle norm referanslı testlerde madde seçiminde, madde ayırt edicilik indeksi daha öncelikli bir kriterdir (Crocker \& Algina, 2006). İlgili maddelerin testten çıkarılıp çıkarılmaması ile ilgili nihai karar DFA sonuçlarına bırakılmıştır.

YFDA kuramsal çerçeve ve uzman görüşleri doğrultusunda üç faktörlü olarak geliştirilmiştir. Bu alt faktörler; yazı yönü, kitap kavramları ve yazı kavramlarıdır. Araştırma kapsamında geliştirilen bu ölçme aracının yapı geçerliğine dair kanıt elde etmek amacıyla DFA analizi yapıımıştır. Elde edilen sonuçlar Tablo 3'de verilmiştir.

Tablo 3.

Ü̧̧faktörlü Yazı Farkındalığı Becerilerini Değerlendirme Aracı'na ait DFA sonuçları

\begin{tabular}{llll}
\hline & Maddeler & Faktör Yükleri & $P$ \\
\hline Yazı Yönü & $\mathrm{m} 13$ & 0.80 & 0.000 \\
& $\mathrm{~m} 14$ & 0.96 & 0.000 \\
& $\mathrm{~m} 15$ & 0.59 & 0.000 \\
& $\mathrm{~m} 16$ & 0.82 & 0.000 \\
& $\mathrm{~m} 17$ & 0.70 & 0.000 \\
& $\mathrm{~m} 18$ & 0.72 & 0.000 \\
& $\mathrm{~m} 19$ & 0.72 & 0.000 \\
\hline Kitap Kavramları & $\mathrm{m} 2$ & 0.65 & 0.000 \\
& $\mathrm{~m} 3$ & 0.71 & 0.000 \\
& $\mathrm{~m} 4$ & 0.32 & 0.000 \\
& $\mathrm{~m} 5$ & 0.15 & 0.289 \\
& $\mathrm{~m} 6$ & 0.57 & 0.000 \\
& $\mathrm{~m} 7$ & 0.31 & 0.005 \\
& $\mathrm{~m} 8$ & 0.55 & 0.000
\end{tabular}




\begin{tabular}{llll}
\hline & Maddeler & Faktör Yükleri & $\mathrm{P}$ \\
\hline & $\mathrm{m} 9$ & 0.46 & 0.000 \\
\hline Yazı Kavramları & $\mathrm{m} 12$ & 0.35 & 0.001 \\
& $\mathrm{~m} 20$ & 0.94 & 0.000 \\
& $\mathrm{~m} 21$ & 0.98 & 0.000 \\
& $\mathrm{~m} 22$ & 0.52 & 0.000 \\
& $\mathrm{~m} 23$ & 0.67 & 0.000 \\
& $\mathrm{~m} 24$ & 0.44 & 0.000 \\
& $\mathrm{~m} 25$ & 0.46 & 0.000 \\
& $\mathrm{~m} 26$ & 0.74 & 0.000 \\
& $\mathrm{~m} 27$ & 0.45 & 0.000 \\
\hline
\end{tabular}

Elde edilen DFA sonuçlarına göre, yazı yönü alt faktöründe yer alan yedi maddeye ait faktör yükleri 0.59 ile 0.96 arasında değişmektedir. Bu katsayıların tamamı 0.05 düzeyinde istatistiksel olarak anlamlıdır. Diğer bir ifadeyle maddelerin tamamı yazı yönü örtük değişkeni tarafından anlamlı bir şekilde yordanmaktadır. Bu faktörü en çok açıklayan maddenin 14. madde; en az açıklayan maddenin ise 15. madde olduğu görülmektedir.

Kitap kavramları alt boyutunda yer alan sekiz maddenin faktör yükleri 0.15 ile 0.71 arasında değişmektedir. 5. madde haricindeki diğer maddelerin tamamı 0.05 düzeyinde anlamlıdır. 5. madde ilgili faktörü anlamlı bir şekilde açıklamamıştır. Bu nedenle 5. maddenin değerlendirme aracından çıkarılmasına karar verilmiştir.

Yazı kavramları alt boyutunda dokuz maddeye ait faktör yükleri 0.35 ile 0.98 arasında değişmektedir. Bu katsayıların tamamı 0.05 düzeyinde anlamlıdır. Diğer bir ifadeyle bu maddelerin tamamı ilgili örtük değişken tarafından anlamlı bir şekilde yordanmaktadır.

Yukarıda yapılan madde analizi bulgularına göre madde güçlük düzeyi 0.20'nin altında olan 6 . 21. ve 22. maddeleri için faktör yükü değerleri 0.57 ile 0.98 arasında değişmiş̧ir. Elde edilen bulgular bu maddelerin kendi alt boyutlarında anlamlı birer yordayıcı olduğunu göstermektedir. Bu sonuçlardan hareketle 6, 21 ve 22. maddelerin YFDA'nın nihai formunda kalmasına karar verilmiştir.

Üç faktörlü YFDA'nın yapı geçerliğine kanıt elde etmek için yapılan DFA sonucunda elde edilen uyum istatistikleri Tablo 4'de verilmiştir.

Tablo 4.

Üç faktörlü Yazı Farkındalığı Becerilerini Değerlendirme Aracı'na ait uyum istatistikleri

\begin{tabular}{llccc}
\hline$\chi^{2}(\mathrm{sd})$ & $\chi^{2} / \mathrm{sd}$ & RMSEA & CFI & TLI \\
\hline $395.56(249)^{*}$ & 1.59 & 0.052 & .93 & .93 \\
\hline
\end{tabular}

$* p<.05$

Tablo 4 incelendiğinde, RMSEA değeri yaklaşık olarak $0.052, \mathrm{CFI}=0.93, \mathrm{TLI}=0.93$ ve $\chi^{2} /$ sd ise 1.59 'dur. Elde edilen tüm değerler YFDA'nın üç faktörlü yapısının veriye uyum sağladığına işaret etmektedir.

Sonuç olarak araştırma kapsamında 27 maddeden oluşturulan YFDA'ya ait yapılan madde analizi sonuçları doğrultusunda 1., 10. ve 11. maddeler testten çıkarılmıştır. Bu sonuçlara ek olarak, ölçme aracının üç faktörlü yapısının yapı geçerliğine kanıt elde etmek amacıyla yapılan DFA sonucunda 5. madde içinde yer aldığı faktörü anlamlı bir şekilde yordamadığı için ölçme aracından çıkarılmıştır. Elde edilen bu sonuçlara göre YFDA'nın nihai formu 23 maddeden oluşmaktadır. Testin bu nihai formuna ait test istatistikleri Tablo 5'te verilmiştir. 
Okul Öncesi Dönemdeki Çocukların Yazı Farkındalığı Becerilerini Değerlendirme Aracı'nın Geçerlik ve Güvenirlik Çalışması

Tablo 5.

Yazı Farkındalığı Becerilerini Değerlendirme Aracı'nın nihai formuna ait test istatistikleri

\begin{tabular}{|c|c|c|c|c|}
\hline & $\begin{array}{l}\text { Yazı } \\
\text { Yönü }\end{array}$ & $\begin{array}{l}\text { Kitap } \\
\text { Kavramları }\end{array}$ & $\begin{array}{l}\text { Yazı } \\
\text { Kavramları }\end{array}$ & $\begin{array}{l}\text { Testin } \\
\text { Geneli }\end{array}$ \\
\hline $\begin{array}{l}\text { Ortalama Madde Güçlük } \\
\text { İndeksi }\left(\bar{P}_{j}\right)\end{array}$ & 0.82 & 0.50 & 0.42 & 0.57 \\
\hline $\begin{array}{l}\text { Ortalama Madde Ayırt } \\
\text { Edicilik İndeksi }\left(\bar{r}_{\boldsymbol{j} x}\right)\end{array}$ & 0.57 & 0.47 & 0.51 & 0.39 \\
\hline Standart Sapma (Ss) & 1.45 & 1.35 & 1.90 & 3.60 \\
\hline Güvenirlik (KR-20) & 0.68 & 0.44 & 0.66 & 0.76 \\
\hline
\end{tabular}

Tablo 5'de görüldüğü üzere, YFDA'nın yazı yönü alt boyutunda yer alan yedi maddeye ait madde güçlük indekslerine ait ortalama güçlük indeksi değeri 0.82 'dir. Elde edilen bu sonuçlara göre YFDA'nin yazı yönü alt boyutunun genel olarak çocuklar için kolay yapılabilecek becerilerden oluştuğu söylenebilir. Bu faktöre ait madde ayırt edicilik katsayıları dikkate alındığında, ortalama ayırıcılığın 0.57 olduğu görülmektedir. Bu değer testin bu boyutunun genel olarak iyi düzeyde ayırt edici olduğuna işaret etmektedir.

YFDA'nın kitap kavramları alt faktöründe yedi madde bulunmaktadır. Bu maddelerin madde güçlük indeksleri ortalaması 0.50 'dir. Bu değer testin bu boyutun orta güçlükte olduğuna işaret etmektedir. Madde ayırt edicilik katsayıları dikkate alındığında, ortalama ayırt edicilik değerinin 0.47 olduğu görülmektedir. Elde edilen bu bulgulara göre YFDA'nın kitap kavramları alt boyutundaki maddelerin genel olarak iyi düzeyde ayırt edici olduğu söylenebilir.

YFDA'nın yazı kavramları alt faktöründe dokuz madde bulunmaktadır. Bu maddelere ait ortalama madde güçlük değeri $0.42^{\prime}$ dir. Bu sonuçlara göre yazı kavramları alt faktörünün genel olarak orta güçlükte olduğu söylenebilir. Bu faktöre ait madde ayırt edicilik katsayıları dikkate alındığında ortalama ayırt ediciliğin 0.51 olduğu görülmektedir. Bu sonuçlara göre yazı kavramları alt faktöründeki maddelerin genel olarak iyi düzeyde ayırıcılığa sahip oldukları söylenebilir.

Değerlendirme aracının geneli için yapılan analiz sonuçlarına göre, YFDA aracındaki 23 maddeye ait madde güçlük indeksi ortalaması 0.57 , madde ayırt edicilik değerleri ortalaması da 0.39 olarak elde edilmiştir. Bu bulgulardan hareketle, testin genel olarak orta güçlükte ve iyi düzeyde ayırt ediciliğe sahip olduğu söylenebilir. Testten elde edilen puanların güvenirliği için hesaplanan KR-20 değerleri dikkate alındığında, kitap kavramları alt faktörü haricinde diğer faktörlerin genel olarak güvenirlik dereceleri orta düzeydedir. Testin geneli için hesaplanan güvenirlik değeri 0.76 'dır. Bu değer YFDA'dan elde edilen ölçme sonuçlarının genel olarak iyi düzeyde güvenirliğe sahip olduğu söylenebilir.

\section{Tartışma, Sonuç ve Öneriler}

$\mathrm{Bu}$ araştırmada okul öncesi dönemdeki çocukların yazı farkındalığı becerilerini değerlendirmek amacıyla geliştirilen YFDA'nın geçerlik-güvenirlik çalışması yapılmıştır. Bu amaç doğrultusunda öncelikle alanyazın taraması yapılmış ve değerlendirme aracının 27 maddelik ilk taslağı oluşturulmuştur. Kapsam geçerliği için uzmanlardan görüş alınmış ve uzmanların değerlendirmeleri sonucunda aracın kapsam geçerliğine sahip olduğu kararına varılmıştır. Bir ön uygulama yapılarak değerlendirme aracının uygulanma süreci test edilmiştir. YFDA'nın 216 çocuğa uygulanmasıyla elde edilen verilere ilk olarak madde analizi yapılmış ve madde ayırt edicilikleri düşük bulunan üç madde değerlendirme aracından çıkarılmıştır. Ayrıca araştırma kapsamında geliştirilen değerlendirme aracının yapı geçerliğine dair kanıt elde etmek amacıyla DFA yapılmıştır. DFA sonucunda ise bir madde içinde yer aldığı faktörü anlamlı bir şekilde yordamadığı için araçtan çıkarılmıştır. Değerlendirme aracının geneli için hesaplanan güvenirlik değeri 0.76 'dır. Bu sonuçlara göre nihai formu 23 maddeden oluşan YFDA'nın geçerli ve güvenilir olduğu ve anasınıfına devam eden 48-72 ay 
normal gelişim gösteren çocukların yazı farkındalığı becerilerinin değerlendirmek amacıyla kullanılabileceği sonucuna ulaşılmıştır.

Alan yazında yazı ve resim arasındaki ayrımın önemli olduğu, bu ayrımın çocukların yazıyı fark etmelerinde ve yazının işlevini ve yapısını öğrenmelerine olanak sağladığı belirtilmiştir (Christie, Enz, \& Vukelich, 2003). Ancak bu araştırmanın bulguları çerçevesinde yazı ile resim arasındaki farkın değerlendirilmesi ve dolayısıyla yazının işlevinin farkında olup olunmadığının belirlenmesi amacıyla değerlendirme aracında yer verilen iki madde (10. madde; "Bu sayfadaki resimleri göster." ve 11. madde; "Bu sayfadaki yazıları göster") ayırt edicilikleri düşük bulunduğundan araçtan çıkarılmıştır. Bu maddelerin ayırt edicilik katsayılarııı düşük çıkmasının nedeni bu ayrımın çok erken yaşlarda öğrenilmesi olabilir. Yazma gelişimini inceleyen çalışmalarda yazı ve resim arasındaki ayrımın çocukların okuma yazma gelişim sürecinde öğrendikleri ilk kavramlardan biri olduğu ifade edilmektedir (Justice \& Sofka, 2010; Lovelace \& Stewart, 2007). Bu nedenle araştırmaya katılan çocukların büyük çoğunluğunun bu iki maddeyi gerçekleştirdikleri ve maddelerin bu nedenle çalışmadığı düşünülmektedir. Madde ayırt edicilik katsayısı düşük çıkan ve değerlendirme aracından çıkarılan 1. maddenin (kitap okunurken nasıl tutulur göster) de aynı nedenlerle çalışmadığı düşünülmektedir. Kitap okurken kitabın tutuş şekli çocuklar için okul ve ev ortamı da dâhil olmak üzere her yerde ve herkeste görebileceği, yani çok yaşantısal bir beceri olması nedeniyle çocukların büyük çoğunluğunun maddeyi gerçekleştirdikleri düşünülmektedir.

Günümüzde okul öncesi dönem risk altındaki çocuklara erken okuryazarlık becerilerine yönelik erken müdahale programlarının uygulanabilmesi için ölçüme dair çalışmalar büyük bir öneme sahiptir (Justice \& Ezel, 2001). Bu anlamda YFDA alanda çalışan uzmanlara ve eğitimcilere yazı farkındalığı ve yazı kavramlarında yaşıtlarından düşük performans gösteren ve desteğe gereksinimi olan çocukları belirlemede faydalı olabilir. Aynı şekilde bu değerlendirme aracı, geliştirilecek erken okuryazarlık müdahale programlarında ön test ve son test olarak müdahalenin etkililiğini belgelemede ve farklı müdahale yaklaşımlarının göreceli etkilerini karşılaştırmada kullanılabilir. ileri dönemdeki okuryazarlık yeterliliğini güçlü bir şekilde öngören on değişkenden ikisinin yazı kavramları ve yazı farkındalığı becerilerinin olduğu (National Early Literacy Panel [NELP], 2008) göz önünde bulundurulduğunda, bu becerilerde gereksinimi olan çocukların belirlenmesi ve bu çocuklara müdahale edilmesinde alana kazandırılan bu değerlendirme aracının önemli olduğu düşünülmektedir.

Okul öncesi dönemde genel olarak yazı farkındalığı becerilerinin ediniminde (Aram \& Biron, 2004; Justice \& Ezell, 2002; 2004; Justice, Pence, Beckman, Skibbe, \& Wiggins, 2005) ve değerlendirilmesinde (Clay, 2005; Justice \& Ezell, 2001) sıklıkla resimli çocuk kitaplarından yararlanılmaktadır. Çünkü resimli öykü kitabı okuma, hem kitabı doğru tutma, sayfaları soldan sağa çevirme, başlık tanıma, sözcükler ve resimler arasındaki farkı anlama, yazının işlevini fark etme gibi pek çok yazı farkındalığı becerisine yönelik olarak çocukların pratik yapmalarını sağlamakta hem de yazı ile tanışıkıı anlamında çevresel girdilerin zenginleştirilmesinde önemli etkileşimsel bir bağlam sunmaktadır. Ülkemizde daha önce geliştirilmiş benzer nitelikteki yazı farkındalığı değerlendirme araçlarının çoğunda ya araştırmacılar tarafından geliştirilerek hazırlanan (Karaman, 2013; şimşekÇetin \& Alisinanoğlu, 2013) ya da orijinal araçtan Türkçe'ye çevrilerek uyarlanan öykü kitapları kullanılmıştır (Bayraktar, 2013). Bu araştırmada ise bu değerlendirme araçlarından farklı olarak piyasada satılan ve alanda çalışanların daha kolay ulaşabileceği bir öykü kitabı kullanılmıştır. Böylece uzman ve eğitimciler için daha erişilebilir ve uygulanabilir bir değerlendirme aracının alana kazandırıldığı düşünülmektedir.

Ülkemizde 2013 yılında uygulamaya konulan okul öncesi eğitim programı incelendiğinde yeterli sayıda olmasa da yazı farkındalığı ile ilgili kazanım ve göstergelerin (ör., çevresinde bulunan yazılı materyaller hakkında konuşma, yazılı materyallerde noktalama işaretlerini gösterme, yazının yönünü gösterme, duygu ve düşüncelerini bir yetişkine yazdırma, yazının günlük yaşamdaki önemini açıklama) programda yer aldığı görülmektedir. Program bağlamında düşünüldüğünde, araştırma kapsamında geliştirilen değerlendirme aracının okul öncesi dönem çocukların yazı farkındalığı becerilerinin değerlendirilmesinde öğretmenlere yol gösteren, kısa sürede ve kolay uygulanabilen bir değerlendirme sürecini örneklediği düşünülmektedir. Genel olarak okul öncesi dönem çocuklarla 
çalışan öğretmenlere, çocukların etkili öğretimlerle neler yapabileceğini gösteren araştırmalar esas alınarak ortaya konulan standartları kullanmaları önerilmektedir (McGee \& Morrow, 2005). Bu standartlar, bir yıl boyunca öğretmenin ne öğreteceğine karar vermesine ve çocukların gelişimlerini değerlendirmek için gerekli bilgilerin nasıl toplanacağına yol gösterici standartlardır. Bu bağlamda öğretmenlerin sürekli yaptıkları değerlendirmeler sonucunda okuma yazma gelişimlerinde sorun gördükleri çocuklar ile ilgili öğretimsel tedbirler almaları, gerekiyorsa aileleri ya da diğer okul personelini ve yönetimini olası güçlükler konusunda bilgilendirmeleri önemlidir. Araştırmada geçerlik ve güvenirlik çalışmaları yapılan bu değerlendirme aracının, okul öncesi öğretmenlerine yıl boyunca çocuklara yazı farkındalığı becerileri ile ilgili olarak ne öğreteceklerine karar vermelerinde ve çocuklardaki gelişmeleri belgelendirmek için kullanmaya ihtiyaç duydukları değerlendirme içeriğine rehberlik edeceği umulmaktadır. Aynı zamanda, YFDA çocukların performans profillerine bağlı olarak kısa ve uzun dönem erken okuryazarlık hedeflerinin gelişimini izleme için de araştırmacılar ve eğitimciler tarafından kullanılabilir. Sonuç olarak, YFDA ile okul öncesi dönem çocukların yazı farkındalı̆̆ı becerilerine yönelik performanslarına dair yapılacak değerlendirmeler pek çok eğitsel amaca hizmet edebilir.

\section{Kaynaklar}

Aram, D., \& Biron, S. (2004). Joint storybook reading and joint writing interventions among low SES preschoolers: Differential contributions to early literacy. Early Childhood Research Quarterly, $19,588-610$.

Arnold, D. H., \& Doctoroff, G. L. (2003). The early education of socioeconomically disadvantaged children. Annual Review of Psychology, 54(1), 517-545.

Bayraktar, V. (2013). Okuma-yazmaya hazırlık eğitim programının anasınıfına devam eden 6 yaş grubu çocukların yazı farkındalığı becerilerine ve ilkokul birinci sınıftaki ses farkındalığı ve okuma-yazma becerilerine etkisinin incelenmesi (Doktora tezi, Gazi Üniversitesi, Eğitim Bilimleri Enstitüsü, Ankara). https://tez.yok.gov.tr/UlusalTezMerkezi/ adresinden edinilmiştir.

Birden, N. (2015). Oyuncu bulut. Ankara: Kök Yayıncılık.

Brown, T. A. (2015). Confirmatory factor analysis for applied research. New York: Guilford Publications.

Cabell, S.Q., Justice, L.M., Konold, T.R., \& McGinty, A.S. (2011). Profiles of emergent literacy skills among preschool children who are at risk for academic difficulties. Early Childhood Research Quarterly, 26(1), 1-14.

Carroll, J. M., Snowling, M. J., Hulme, C., \& Stevenson, J. (2003). The development of phonological awareness in preschool children. Developmental Psychology, 39, 913-923.

Carroll, J. M., Solity, J., \& Shapiro, L. R. (2016). Predicting dyslexia using prereading skills: the role of sensorimotor and cognitive abilities. Journal of Child Psychology and Psychiatry, 57(6), 750758.

Catts, H. W., Fey, M. E., Tomblin, J. B., \& Zhang, X. (2002). A longitudinal investigation of reading outcomes in children with language impairment. Journal of Speech, Language, and Hearing Research, 45, 1142-1157.

Christie, J., Enz, B., \& Vukelich, C. (2003). Teaching language and literacy: Preschool through the elementary grades (2nd ed.). Boston: Allyn \& Bacon.

Clay, M. (2005). An observation survey of early literacy achievement. (2nd ed.), USA New Zealand: Heinemann.

Crocker, L., \& Algina, J. (2006). Introduction to classical and modern test theory. Belmont: Wadsworth Pub Co.

Çokluk, Ö., Şekercioğlu G., \& Büyüköztürk Ş. (2012). Sosyal bilimler için çok değişkenli istatistik SPSS ve LISREL uygulamaları. Ankara: Pegem Yayınları.

Ergül, C., Akoğlu, G., Sarıca, A. D., Karaman, G., Tufan, M., Bahap-Kudret, Z., \& Deniz, Z. (2016). An adapted dialogic reading program for Turkish kindergarteners from low socio-economic backgrounds. Journal of Education and Training Studies, 4(7), 179-194. 
Ezell, H. K., \& Justice, L. M. (2005). Shared storybook building young children's language and emergent literacy skill. Baltimore: Paul H. Publishing Co.

Farver, J. M., Nakamoto J., \& Lonigan C. J. (2007). Assessing preschoolers' emergent literacy skills in english and spanish with the get ready to read! screening tool. Annals of Dyslexia, 57(2), 161178.

Foster, M. A., Lambert, R., Abbott-Shim, M., McCarty, F., \& Franze, S. (2005). A model of home learning environment and social risk factors in relation to children's emergent literacy and social outcomes. Early Childhood Research Quarterly, 20(1), 13-36.

Ghosh, D.S. (2013). Socioeconomic status links to children's literacy development. Washington University Undergraduate Research Digest, 9(1), 10-15.

Hammill, D. D. (2004). What we know about correlates of reading. Exceptional Children, 70, 453-468.

Invernizzi, M., Sullivan, A., Meier, J., \& Swank, L. (2004). PALS-Pre-K teacher's manual. University of Virginia, Charlottesville, VA.

Israel, S. E. (2008). Early reading first and beyond. London: Corwin Press.

Işıkoğlu-Erdoğan, N., Muslugüme, E., Huz, Ç., Yılmaz, G., \& Öztürk, B. (2015). Okul öncesi eğitimi döneminde isim yazma becerilerinin incelenmesi. Illköğretim Online, 14(2), 449-458.

Işıtan, S., \& Akoğlu, G. (2016). Yazı farkındalığı becerilerinin resimli çocuk kitabı aracılığıyla değerlendirilmesi: Güvenirlik ve geçerlik çalışması. Turkish Studies, 11(3)1333-1352.

Justice, L. M., Bowles, R. P., \& Skibbe, L. E. (2006). Measuring preschool attainment of print-concept knowledge: A study of typical and at-risk 3-to 5-year-old children using item response theory. Language, Speech, and Hearing Services in Schools, 37(3), 224-235.

Justice, L. M., \& Ezell, H. K. (2000). Enhancing children's print and word awareness through homebased parent intervention. American Journal of Speech-Language Pathology, 9(3), 257-269.

Justice, L. M., \& Ezell, H. K. (2001). Word and print awareness in 4-year-old children. Child Language Teaching and Therapy, 17(3), 207-225.

Justice, L. M., \& Ezell, H. K. (2002). Use of storybook reading to increase print awareness in at-risk children. American Journal of Speech-Language Pathology, 11(1), 17-29.

Justice, L. M., \& Ezell, H. K. (2004). Print referencing: An emergent literacy enhancement strategy and its clinical applications. Language, Speech, and Hearing Services in Schools, 35(2), 185-193.

Justice, L. M., Pence, K. L., Beckman, A. R., Skibbe, L. E., \& Wiggins, A. K. (2005). Scaffolding with storybooks: A guide for enhancing young children's language and literacy achievement. Newark, DE: International Reading Association.

Justice, L. M., \& Pullen, P. C. (2003). Promising interventions for promoting emergent literacy skills: Three evidence-based approaches. Topics in Early Childhood Special Education, 23(3), 99-113.

Justice, L. M., \& Sofka, A. E. (2010). Engaging children with print: Building early literacy skills through quality read-alouds. New York: The Guilford Press.

Karaman, G. (2013). Erken okuryazarlık becerilerini değerlendirme aracının geliştirilmesi, geçerlik ve güvenirlik çalışması (Doktora tezi, Gazi Üniversitesi, Eğitim Bilimleri Enstitüsü, Ankara). https://tez.yok.gov.tr/UlusalTezMerkezi/ adresinden edinilmiştir.

Kelman, M. E. (2006). An investigation of preschool children's primary literacy skills (Doctoral dissertation, University of Wichita State, 2006). ProQuest Digital Dissertations, 3261874.

Lerkkanen M.K., Rasku-Puttonen H., Aunola, K., \& Nurmi, J.E. (2004). Development dynamics of phonemic awareness and reading performance during the first year of primary school. Journal of Early Childhood Research, 2(2), 139-156.

Lonigan, C. J., Bloomfield, B. G., Anthony, J. L., Bacon, K. D., Phillips, B. M., \& Samwel, C. S. (1999). Relations among emergent literacy skills, behavior problems, and social competence in preschool children from low- and middle-income backgrounds. Topics in Early Childhood Special Education, 19, 40-53.

Lovelace, S., \& Stewart, S. R. (2007). Increasing print awareness in preschoolers with language impairment using non-evocative print referencing. Language, Speech, and Hearing Services in Schools, 38, 16-30. 
Matsunaga, M., (2010). How to factor-analyze your data right: Do's, don'ts, and how-to's. International Journal of Psychological Research, 3(1), 98-111.

McCardle, P., Scarborough, H. S., \& Catts, H. W. (2001). Predicting, explaining, and preventing children's reading difficulties. Learning Disabilities Research \& Practice, 16(4), 230-239.

McGee, L. M., \& Morrow, M. L. (2005). Teaching literacy in kindergarten. New York: Guilford Press.

McGee, L. M., \& Richgels, D. J. (2014). Designing early literacy programs: Differentiated instruction in preschool and kindergarten. New York: Guilford Press.

Nancollis, A., Lawrie, B. A., \& Dodd, B. (2005). Phonological awareness intervention and the acquisition of literacy skills in children from deprived social background. Language, Speech \& Hearing Services in Schools, 36(4), 325-352.

National Early Literacy Panel [NELP]. (2008). Developing early literacy: Report of the National Early Literacy Panel. Washington, DC: National Institute for Literacy.

Pesova, B., Sivevska, D., \& Runceva, J. (2014). Early intervention and prevention of students with specific learning disabilities. Procedia-Social and Behavioral Sciences, 149, 701-708.

Pohlmann, J. T. (2004). Use and interpretation of factor analysis in The Journal of Educational Research: 1992-2002. The Journal of Educational Research, 98(1), 14-23.

Pullen, P. C., \& Justice, L. M. (2003). Enhancing phonological awareness, print awareness, and oral language skills inpreschool children. Intervention in School and Clinic, 39(2), 87-98.

Reutzel, R. (2015). Early literacy research: Findings primary-grade teachers will want to know. The Reading Teacher, 69(1), 14-24.

Sarı, B., \& Acar, E. A. (2013). Erken çocukluk dönemi fonolojik duyarlılık ölçeğinin (EÇDFDÖ) geliştirilmesi ve psikometrik özellikleri. Kuram ve Uygulamada Eğitim Bilimleri, 13(4), 21952215.

Snow, C., Burns, M. S., \& Griffin, P. (Eds.). (1998). Preventing reading difficulties in young children. Washington, DC: National Academy Press. http://www.nap.edu/openbook.php?record_id=6023 sayfasından erişilmiştir.

Sodoro, J., Allinder, R. M., \& Rankin-Erickson, J. L. (2002). Assessment of phonological awareness: Review of methods and tools. Educational Psychology Review, 14(3), 223-260.

Spira, E. G., Bracken, S. S., \& Fischel, E. J. (2005). Predicting improvement after first grade reading difficulties: The effects of oral language, emergent literacy, and behavior skills. Developmental Psychology, 41, 225-234.

Storch, S. A., \& Whitehurst, G. J. (2002). Oral language and code-related precursors to reading: Evidence from a longitudinal structural model. Developmental Psychology, 38(6), 934-947.

Şimşek-Çetin, Ö., \& Alisinanoğlu, F. (2013). Okul öncesi dönemdeki çocukların yazı farkındalığını değerlendirme kontrol listesinin geçerlik ve güvenirlik çalışması. Karadeniz Sosyal Bilimler Dergisi, 8, 15-27.

Tan, Ş. (2010). Öğretimde ölçme ve değerlendirme. Ankara: Pegem Akademi.

Tekindal, S. (Ed.) (2008). Eğitimde ölçme ve değerlendirme. Ankara: Pegem Akademi.

van Kleeck, A. (2003). Research on book sharing: Another critical look. In A. van Kleeck, S. A. Stahl, \& E. B. Bauer (Eds.), On reading books to children: Parents and teachers (pp. 271-320). Mahwah, NJ: Erlbaum.

Vellutino, F., Scanlon, D. M., \& Lyon, R. G. (2003). Differentiating between difficult-to-remediate poor readers. Journal of Learning Disabilities, 33(3), 223-239.

Walpole, S., Chow, S. M., \& Justice, L. M. (2004). Literacy achievements during kindergarten: Examining key contributors in an at-risk sample. Early Education and Development, 15, 245264. 


\section{Extended Abstract Introduction}

Children gain preliminary skills necessary for literacy in the pre-school period and take their first steps in becoming literate. They develop skills in listening comprehension, vocabulary, print awareness and print concepts, alphabet knowledge, letter-sound correspondence and comprehension of alphabetical principles and phonological awareness (McGee \& Morrow, 2005; McGee \& Richgels, 2014). Print awareness is the recognition of the fact that writing carries a message separate from the visuals and verbal language, that it is a communication tool, and that there is a relationship between writing and speaking (Ezell \& Justice, 2005). Assessment and instruction of print awareness and print concepts link children's successive literacy competence (Reutzel, 2015). Many studies show that literacy skills successfully predict children's future reading achievement (Farver, Nakamoto, \& Lonigan, 2007; Hammill, 2004; Spira, Bracken, \& Fischel, 2005; Vellutino, Scanlon, \& Lyon, 2003).

Children develop their print awareness skills by engaging in literacy-based interaction with adults and they learn about print by analyzing the texts around and by observing how people use printed materials (Ezell \& Justice, 2005; Justice \& Sofka, 2010; Pullen \& Justice, 2003). However, due to a variety of reasons, children do not know much about writing in the pre-school period and there could be various problems in the development of their print awareness skills (McGee \& Morrow, 2005; Pullen \& Justice, 2003). Problems in early literacy skills may be an important indicator of future challenges in literacy development (Justice \& Ezell, 2001). When the importance of print awareness for literacy skills is considered, it is crucial to identify the children having difficulty in developing writing skills in their pre-school period (Justice, Bowles, \& Skibbe, 2006).

Children who are growing up in a low socioeconomic environment with limited knowledge and experience in early literacy skills and those with language disorders and with developmental disabilities are at risk for literacy development (Arnold \& Doctoroff, 2003; Ezell \& Justice, 2005; Justice \& Pullen, 2003; McGee \& Richgels, 2014). Nowadays, studies on the assessment of early intervention programs for early literacy skill development of pre-school children at risk are significant (Justice \& Ezel, 2001). This research aims to develop an assessment tool to determine children with delayed early literacy development and to identify the effectiveness of literacy intervention on early literacy skills and to conduct its validity and reliability.

\section{Method}

The study group consisted of 216 children (109 girls and 107 boys) aged $48-72$ months who displayed normal development. The first version of the Assessment Tool for Print Awareness Skills (ATPAS) had three factors and 27 items that included the direction of writing, book concepts, and print concepts. A 16-page storybook named "Oyuncu Bulut" (Gamer Cloud) (Birden, 2015) was used in the assessment of all the items in the ATPAS.

Opinions from experts were obtained to establish content validity. Item analysis was also performed on the collected data. Afterwards, a confirmatory factor analysis (CFA) was conducted for construct validity. The CFA showed that the three-factor model fit the data. The items whose discrimination parameters were found close to 0 were removed from the tool. The reliability of the tool was calculated using the KR-20 internal consistency coefficient.

\section{Result and Discussion}

In this study, the validity and reliability analyses of ATPAS, which was developed to assess the print awareness skills of the pre-school children, were conducted. The reliability value of the tool was found to be 0.76 . This value indicated that the measurement results obtained from the tool had a significant level of reliability. It was found that the reliability degrees of factors were generally moderate except for the subscale of book concepts, and the final form of the ATPAS was composed of 23 items. 
The findings suggested that ATPAS had adequate validity and reliability for evaluating the print awareness skills of Turkish kindergarten children. It may help identify children who are at risk for literacy development and who are underperforming in print awareness and print concepts. This tool can also be used to document the effectiveness of any intervention when used as a pre/posttest in early literacy intervention programs to be developed and to compare the relative impact of different intervention approaches.

\section{Ek-1. Okul Öncesi Dönemde Yazı Farkındalığını Becerilerini Değerlendirme Aracı}

Çocuk (Ad/Soyad) Tarih: ............/20...... Cinsiyet: .......K /......E Doğum Tarihi: .................... 48-60 ay $\square 60-72$ ay

Uygulama: Bu değerlendirme sürecinde "Oyuncu Bulut" (Birden, 2015) kitabını kullanınız. Uygulama sırasında çocuğun yanına oturunuz ve okuma boyunca kitabı onun da görebileceği şekilde tutunuz. Çocuğa önce "Şimdi seninle birlikte bu kitabı okuyacağız, bu kitabı okurken senin yardımına ihtiyacım olacak, sen de bana yardım edeceksin, tamam mı?" şeklinde ana yönergeyi veriniz. Ardından aşağıdaki soruları, kitap okuma sırasında ilgili sayfa numarasına göre sorunuz. Her sayfada soracağınız soruyu daha kolay hatırlayabilmek, okuma sırasında akıcılığını bozmamak ve kitaptaki konudan uzaklaşmamak için hangi sayfada değerlendirme aracındaki kaç numaralı soruyu/soruları soracağınızı kitabın sayfalarına öğrencinin dikkatini çekmemesi amacıyla silik bir şekilde not ediniz. Kitap okuma sırasında o sayfaya ait soruyu öğrenciye sorunuz. Çocuğun tepkisiz kalması durumunda soruyu bir kez daha tekrarlayınız. Çocuğun tepki ve cevaplarını herhangi bir şekilde pekiştirmeyiniz ya da ona ipucu vermeyiniz. Değerlendirme sırasında öğrencinin her bir madde için istenen/beklenen tepkiyi vermesi durumunda ilgili maddede doğru tepkiye 1 puan veriniz. Öğrencinin istenen/beklenen tepkiyi vermemesi ya da tepkisiz kalması durumunda ise 0 (sıfır) puan veriniz. Puanları, değerlendirme sırasında çocuktan tepki alır almaz formda ilgili maddenin karşısındaki puan kısmına yazınız. Öğrencinin tekrarlanmasına rağmen yönergeyi anlamadığını düşünürseniz ya da maddelerle ilgili beklenmeyen bir tepki alırsanız formdaki açıklamalar kısmına kısa notlar alınız.

\begin{tabular}{|c|c|c|c|c|c|}
\hline No & \begin{tabular}{|l|} 
Yazı \\
Farkındalı̆̆ı \\
Becerileri \\
\end{tabular} & Sayfa No & Yönergeler ve Puanlandırma & Puan & Açıklama \\
\hline 1. & $\begin{array}{l}\text { Kitap } \\
\text { Kavramları }\end{array}$ & Kapak & $\begin{array}{l}\text { Kitabın ön yüzü üste gelecek şekilde kitap } \\
\text { masanın üstüne ve çocuğun önüne gelecek } \\
\text { şekilde konarak: } \\
\text { Kitabın ön yüzünü göster. } \\
1 \text { Puan: Kitabın ön yüzünü gösterir. }\end{array}$ & & \\
\hline 2. & $\begin{array}{l}\text { Kitap } \\
\text { Kavramları }\end{array}$ & Kapak & $\begin{array}{l}\text { Kitabın ön yüzü üste gelecek şekilde kitap } \\
\text { masanın üstünde ve çocuğun önündeyken: } \\
\text { Kitabın adı nerede yazıyor, göster. } \\
1 \text { Puan: Kitabın adında bir ya da birkaç } \\
\text { sözcüğü gösterir. }\end{array}$ & & \\
\hline 3. & $\begin{array}{l}\text { Kitap } \\
\text { Kavramları / } \\
\text { Yazının } \\
\text { Anlamı }\end{array}$ & Kapak & $\begin{array}{l}\text { Kitabın adı işaret edilerek: } \\
\text { Sence burada ne yazıyor olabilir? Söyle. } \\
1 \text { puan: Kitabın adıyla ya da konusuyla ilgili } \\
\text { bir ya da daha fazla kelime söyler. }\end{array}$ & & \\
\hline 4. & \begin{tabular}{|l|} 
Kitap \\
Kavramları
\end{tabular} & Kapak & $\begin{array}{l}\text { Kitap yazan kişiye ne denir, söyle. } \\
1 \text { Puan: Kitap yazan kişiye yazar dendiğini }\end{array}$ & & \\
\hline
\end{tabular}




\begin{tabular}{|c|c|c|c|c|c|}
\hline No & $\begin{array}{l}\text { Yazı } \\
\text { Farkındalığı } \\
\text { Becerileri } \\
\end{array}$ & Sayfa No & Yönergeler ve Puanlandırma & Puan & Açıklama \\
\hline & & & söyler. & & \\
\hline 5. & $\begin{array}{l}\text { Kitap } \\
\text { Kavramları }\end{array}$ & Kapak & $\begin{array}{l}\text { Kitabın ön yüzü üste gelecek şekilde kitap } \\
\text { masanın üstüne ve çocuğun önüne gelecek } \\
\text { şekilde tekrar konarak: } \\
\text { Kitabın yazarının adı nerede yazıyor, göster. } \\
1 \text { Puan: Kitap kapağında yazarın adını } \\
\text { gösterir. }\end{array}$ & & \\
\hline 6. & $\begin{array}{l}\text { Kitap } \\
\text { Kavramları }\end{array}$ & Kapak & $\begin{array}{l}\text { Bir kitaptaki resimleri çizen kişiye ne denir, } \\
\text { söyle. } \\
1 \text { Puan: Kitabın resimlerini çizen kişiye } \\
\text { ressam dendiğini söyler (resimleyen, } \\
\text { ressam, çizen, çizer sözcükleri de doğru } \\
\text { kabul edilir). }\end{array}$ & & \\
\hline 7. & $\begin{array}{l}\text { Kitap } \\
\text { Kavramları }\end{array}$ & Kapak & $\begin{array}{l}\text { Bu kitabın yayınevinin adı/logosu nerede? } \\
\text { Göster. } \\
1 \text { Puan: Kitap kapağında yayınevinin adını ya } \\
\text { da logosunu gösterir }\end{array}$ & & \\
\hline 8. & $\begin{array}{l}\text { Yazı Kavramı } \\
\text { ve Yazının } \\
\text { İşlevi }\end{array}$ & $\begin{array}{l}\text { 1. ve } 2 . \\
\text { Sayfa }\end{array}$ & $\begin{array}{l}\text { Kitaptaki ilk sayfa işaret edilerek: } \\
\text { Bu sayfayı sana okumak istiyorum. Nereyi } \\
\text { okuyacağımı bana göster. } \\
1 \text { Puan: Sayfadaki yazıyı gösterir. }\end{array}$ & & \\
\hline 9. & $\begin{array}{l}\text { Yazı Yönü } \\
\text { (Yazının } \\
\text { Başlangıcı) }\end{array}$ & 2. Sayfa & $\begin{array}{l}\text { Kitapta ikinci sayfa işaret edilerek: } \\
\text { Buraya bak, şimdi kitabı okumaya } \\
\text { başlayacağım. Yazıları nereden okumaya } \\
\text { başlayacağımı bana göster. } \\
1 \text { puan: Sayfadaki en üst satırdaki ilk } \\
\text { sözcüğü gösterir. }\end{array}$ & & \\
\hline 10. & $\begin{array}{l}\text { Yazı Yönü } \\
\text { (Yazının } \\
\text { Sonu) }\end{array}$ & 2. Sayfa & $\begin{array}{l}\text { Kitabın ikinci sayfası işaret edilerek: } \\
\text { Buraya bak, şimdi bu sayfayı okuyacağım. } \\
\text { Yazıları okumayı nerede bitireceğimi bana } \\
\text { göster. } \\
1 \text { puan: Sayfadaki en alt satırdaki son } \\
\text { sözcüğü gösterir. }\end{array}$ & & \\
\hline 11. & $\begin{array}{l}\text { Yazı Yönü } \\
\text { (Yazının } \\
\text { soldan sağa } \\
\text { okunuş } \\
\text { yönü) }\end{array}$ & $\begin{array}{l}\text { 3. ve } 4 . \\
\text { Sayfa }\end{array}$ & $\begin{array}{l}\text { Kitabın sol ve sağ sayfaları işaret edilerek: } \\
\text { Bu iki sayfaya bak, önce hangi sayfayı } \\
\text { okuyacağım? Bana göster. } \\
1 \text { puan: Kitabın sol sayfasını gösterir. }\end{array}$ & & \\
\hline
\end{tabular}


Okul Öncesi Dönemdeki Çocukların Yazı Farkındalığı Becerilerini Değerlendirme Aracı'nın Geçerlik ve Güvenirlik Çalışması

\begin{tabular}{|c|c|c|c|c|c|}
\hline No & \begin{tabular}{|l|} 
Yazı \\
Farkındalığı \\
Becerileri \\
\end{tabular} & Sayfa No & Yönergeler ve Puanlandırma & Puan & Açıklama \\
\hline 12. & $\begin{array}{l}\text { Yazı Yönü } \\
\text { (Yazının } \\
\text { soldan sağa } \\
\text { okunuş } \\
\text { yönü) }\end{array}$ & 3. Sayfa & $\begin{array}{l}\text { Sayfadaki ilk cümlenin ilk sözcüğü işaret } \\
\text { edilerek: Şimdi ben buradan okumaya } \\
\text { başlıyorum, ne tarafa doğru okuyacağımı } \\
\text { parmağınla işaret ederek göster. } \\
1 \text { puan: Yazının soldan sağa doğru yönünü } \\
\text { işaret eder. }\end{array}$ & & \\
\hline 13. & $\begin{array}{l}\text { Yazı Yönü } \\
\text { (Yazının } \\
\text { yukarıdan } \\
\text { aşağıya } \\
\text { okunuş } \\
\text { yönü) } \\
\end{array}$ & 4. Sayfa & $\begin{array}{l}\text { Sayfadaki ilk satır işaret edilerek: } \\
\text { Sayfadaki bu ilk satırı okumayı bitirdim, } \\
\text { şimdi nereden okumaya devam edeceğimi } \\
\text { bana göster. } \\
1 \text { puan: Ikinci satırım ilk kelimesini gösterir. }\end{array}$ & & \\
\hline 14. & $\begin{array}{l}\text { Yazı Yönü } \\
\text { (Yazının } \\
\text { Sayfa Yönü) }\end{array}$ & 4. sayfa & $\begin{array}{l}\text { Kitabın sol sayfası işaret edilerek: } \\
\text { Bu sayfayı okumayı bitirdim, şimdi nereyi } \\
\text { okuyacağımı bana göster. } \\
1 \text { puan: Sağ sayfayı işaret eder. }\end{array}$ & & \\
\hline 15. & $\begin{array}{l}\text { Yazı Yönü } \\
\text { (Yazının } \\
\text { Sayfa Yönü) }\end{array}$ & 4. Sayfa & $\begin{array}{l}\text { Kitabın sağ sayfası işaret edilerek: } \\
\text { Bu sayfayı okumayı bitirdim, şimdi okumaya } \\
\text { nereden devam edeceğim bana göster. } \\
1 \text { puan: Kitabı çevirir ve sol sayfaya işaret } \\
\text { eder. }\end{array}$ & & \\
\hline 16. & $\begin{array}{l}\text { Yazıya Ait } \\
\text { Alt } \\
\text { Kavramlar } \\
\text { (Sözcük) } \\
\end{array}$ & 4. Sayfa & $\begin{array}{l}\text { Bu sayfada bana bir sözcük göster. } \\
1 \text { puan: Sayfada her hangi bir sözcüğü } \\
\text { gösterir. }\end{array}$ & & \\
\hline 17. & $\begin{array}{l}\text { Yazıya Ait } \\
\text { Alt } \\
\text { Kavramlar } \\
\text { (Sözcük) }\end{array}$ & 4. Sayfa & $\begin{array}{l}\text { Bu sayfadaki yazıda kaç sözcük var, sayıp } \\
\text { söyle. } \\
1 \text { puan: Sözcükleri sayar ve kaç tane } \\
\text { olduğunu söyler. }\end{array}$ & & \\
\hline 18. & $\begin{array}{l}\text { Yazıya Ait } \\
\text { Alt } \\
\text { Kavramlar } \\
\text { (Sözcük) }\end{array}$ & 14. Sayfa & $\begin{array}{l}\text { Bu sayfada birbirinin aynısı olan iki sözcük } \\
\text { var. Bu sözcükleri bana göster. } \\
1 \text { puan: Birbirinin aynı olan iki sözcüğü (pırıl } \\
\text { pırıl) gösterir. }\end{array}$ & & \\
\hline 19. & $\begin{array}{l}\text { Yazıya Ait } \\
\text { Alt } \\
\text { Kavramlar } \\
\text { (Sözcük } \\
\text { Arası } \\
\text { Boşluk) } \\
\end{array}$ & 9. Sayfa & $\begin{array}{l}\text { Bana bu cümlede sözcükler arasında } \\
\text { bulunan boşluklardan bir tanesini göster. } \\
1 \text { puan: Sayfadaki kelimeler arası } \\
\text { boşluklardan birini gösterir. }\end{array}$ & & \\
\hline 20. & $\begin{array}{l}\text { Yazıya Ait } \\
\text { Alt } \\
\text { Kavramlar } \\
\text { (Harf) } \\
\end{array}$ & 13. Sayfa & $\begin{array}{l}\text { Bana bu sayfada bir harf göster. } \\
1 \text { puan: Sözcük içinde bir harf gösterir. }\end{array}$ & & \\
\hline
\end{tabular}


Arzu DOĞANAY BiLGi, Davut ASLAN, Gökhan AÇıKGÖZ

\begin{tabular}{|c|c|c|c|c|c|}
\hline No & \begin{tabular}{|l|} 
Yazı \\
Farkındalı̆̆ı \\
Becerileri
\end{tabular} & Sayfa No & Yönergeler ve Puanlandırma & Puan & Açıklama \\
\hline 21. & $\begin{array}{l}\text { Yazıya Ait } \\
\text { Alt } \\
\text { Kavramlar } \\
\text { (Harf) }\end{array}$ & 14. Sayfa & $\begin{array}{l}\text { Bazı harfler küçük, bazı harfler büyük } \\
\text { harflerdir. Bana bu sayfada büyük harf } \\
\text { göster. } \\
1 \text { puan: Sözcük içinde büyük bir harf } \\
\text { gösterir. }\end{array}$ & & \\
\hline 22. & $\begin{array}{l}\text { Yazıya Ait } \\
\text { Alt } \\
\text { Kavramlar } \\
\text { (Noktalama } \\
\text { İşaretleri) } \\
\end{array}$ & 15. Sayfa & $\begin{array}{l}\text { Bu sayfadaki yazıda cümlelerin bittiğini } \\
\text { anlamama yarayan birkaç tane nokta var. } \\
\text { Bana bu noktalardan bir tanesini göster. } \\
1 \text { puan: Noktayı gösterir. }\end{array}$ & & \\
\hline 23. & $\begin{array}{l}\text { Yazıya Ait } \\
\text { Alt } \\
\text { Kavramlar } \\
\text { (Noktalama } \\
\text { İşaretleri) } \\
\end{array}$ & 12. Sayfa & $\begin{array}{l}\text { Bu sayfadaki yazıda soru sorulduğunu } \\
\text { anlamama yarayan bir soru işareti var. Bana } \\
\text { bu soru işaretini göster. } \\
1 \text { puan: Soru işaretini gösterir. }\end{array}$ & & \\
\hline
\end{tabular}

